J. Clin. Chem. Clin. Biochem.

Vol. 24, 1986, pp. 433-436

(C) 1986 Walter de Gruyter \& Co.

Berlin - New York

\title{
Serum Enzymes of Collagen Synthesis and Type III Procollagen Amino-propeptide in Nigerian Patients with Sickle Cell Disease
}

\author{
By $M$. Bolarin \\ Department of Clinical Pathology, College of Medicine, Lagos University, Lagos, Nigeria
}

(Received August 19/December 16, 1985)

\begin{abstract}
Summary: Serum immunoreactive prolyl hydroxylase protein, galaçtosylhydroxylysyl glucosyltransferase activity and the aminoterminal propeptide of type III procollagen were measured in 20 patients with sickle cell disease and the values were compared with those in 20 apparently healthy Nigerians. The means for the two enzymes and serum aminoterminal propeptide of type III procollagen were significantly higher in the sickle cell disease patients. Significant correlations were found between the values for the two enzymes and the protein serum aminoterminal propeptide of type III procollagen within the sickle cell disease patients. The data confirm that collagen formation is found in the liver, bone and other organs of patients with this disease. The measurement of serum immunoreactive prolyl hydroxylase protein, serum galactosylhydroxylysyl glucosyltransferase activity and serum aminoterminal propeptide of type III procollagen in prospective studies might be helpful in predicting hepatic, bone or diffuse fibrogenesis in sickle cell disease.
\end{abstract}

\section{Enzyme der Kollagensynthese und Typ III-Prokollagen-Aminopropeptid im Serum nigerianischer Patienten mit} Sichelzellkrankheit

Zusammenfassung: Immunreaktives Prolylhydroxylase-Protein, katalytische Aktivität von Galaktosylhydroxylysyl-Glucosyltransferase und das aminoterminale Propeptid vom Typ III Prokollagen wurden im Serum bei 20 Patienten mit Sichelzellanämie gemessen. Die Werte wurden mit denen von 20 offensichtlich gesunden Nigerianern verglichen. Die Mittelwerte für die beiden Enzyme und das aminoterminale Propeptid von Typ III Prokollagen waren bei den Patienten mit Sichelzellanämie signifikant höher. Signifikante Korrelationen wurden zwischen den Werten für die beiden Enzyme und das aminoterminale Propeptid von Typ III Prokollagen innerhalb der Sichelzellanämiepatienten festgestellt. Die Daten bestätigen, daß Kollagenbildung in Leber, Knochen und anderen Organen von Patienten mit dieser Erkrankung vorkommt. Die Messung der drei Kenngrößen bei prospektiven Studien könnte für die Vorhersage der Kollagenfaserbildung in der Leber, in Knochen, oder diffus bei Sichelzellanämie hilfreich sein.

\section{Introduction}

Increased hepatic connective tissue deposition is found in many acute and chronic diseases of varying aetiologies (1). The extent and progress are usually assessed by histopathological examination of biopsy specimens. Dișadvantages of the histological examination are that the actual rate of collagen synthesis is difficult to assess and that biopsies cannot be repeated as often as one may desire. Attempts have therefore been made to develop methods for the estimation of ongoing hepatic, bone, or diffuse collagen synthesis, using serum samples.

The biosynthesis of collagen involves a number of enzymatic modifications, many of which are unique to collagens and a few other proteins with collagenlike amino acid sequences $(2-4)$. Two post-transla- 
tional enzymes can be estimated in serum in the form of immunoreactive prolyl hydroxylase protein and galactosylhydroxylysyl glucosyltransferase activity (5-11). Increased serum immunoreactive prolyl hydroxylase protein and serum galactosylhydroxylysyl glucosyltransferase activity have been reported in patients with various liver diseases $(5-12)$. The two serum enzymes correlate significantly with the respective enzyme activities in liver biopsy specimens, which indicates that serum immunoreactive prolyl hydroxylase protein and serum galactosylhydroxylysyl glucosyltransferase activity may give useful information on actual hepatic collagen formation $(10,12,13)$.

A radioimmunoassay for the measurement of the serum amino-terminal propeptide of type III procollagen is now available (14). The procollagens are biosynthetic precursors of various genetically distinct collagen types. They are processed to collagens by the enzymatic cleavage of their amino- and carboxyterminal extensions in the extracellular matrix $(2,4)$. Increased serum aminoterminal propeptide of type III procollagen concentrations have been found especially in several liver diseases $(14,15)$. No data have so far been reported concerning sickle cell disease, nor is it known whether the collagen laid down in liver, bone or other organs of patients with sickle cell disease $(16-19)$ can be detected by the measurement of serum immunoreactive prolyl hydroxylase protein, serum galactosylhydroxylysyl glucosyltransferase activity and serum aminoterminal propeptide of type III procollagen.

This communication reports our preliminary findings in the clinical application of radioimmunoassay techniques for separate determination of serum immunoreactive prolyl hydroxylase protein and serum aminoterminal propeptide of type III procollagen in patients with sickle cell disease. The serum galactosylhydroxylysyl glucosyltransferase activity was also measured in the same patients.

\section{Patients and Methods}

A total of twenty homozygous sickle cell patients, age 5-18 years, were examined. A reference control group of healthy Nigerians, sex- and age-matched, was also included in the investigation. Patients were first seen in the outpatient department of the University of Ife Teaching Hospitals, Ile-Ife. All the patients were asymptomatic at the time blood samples were taken for the assays; the only complaints were of moderate lassitude. Icterus was mild, but the liver was palpable in 11 or $55 \%$ of these patients. The diagnosis of sickle cell disease was based on clinical observation and confirmed by the finding of a haemoglobin SS pattern on cellulose acetate strip electrophoresis in the laboratory, after preliminary investigation had revealed very low haemoglobin and haematocrit values. All the control subjects had haemoglobin AA and no evidence of liver disease.
In both patients and controls, sera were separated after allowing the blood samples to coagulate for $2 \mathrm{~h}$ at room temperature and were stored frozen at $-20^{\circ} \mathrm{C}$ until assayed for serum immunoreactive prolyl hydroxylase protein and serum aminoterminal propeptide of type III procollagen total protein levels. All serum samples were either aliquots of samples taken for diagnostic purposes or were obtained with the permission of the patients.

Serum immunoreactive prolyl hydroxylase protein was measured with a direct radioimmunoassay based on the displacement of radioactively labelled human prolyl hydroxylase protein from its antibody by the non-labelled human enzyme protein and the precipitation of the enzyme protein-antibody complex by a cellulose-bound second antibody $(11,12)$. Pure human prolyl hydroxylase protein was used as the standard enzyme. The samples were assayed in duplicates and serum enzyme protein concentrations were expressed as mg per liter. Serum aminoterminal propeptide of type III procollagen was measured using a radioimmunoassay kit (Behringwerke $A G$, Germany) based on the displacement of radioactively-labelled type III aminoterminal propeptide and the subsequent precipitation of the peptide-antibody complex by a second antibody (13). Serum galactosylhydroxylysyl glucosyltransferase activity was measured by the method of Myllyla et al. (20), as modified for human serum samples (21).

A standard hospital laboratory method was used for the determination of serum alanine aminotransferase in 15 of our patients. It proved impossible to assay alanine aminotransferase in the remaining 5 patients as the serum samples were too small.

The statistical significances of the differences between two means were calculated by Student's t-test and the correlations were determined by linear regression analysis.

\section{Results}

The mean serum immunoreactive prolyl hydroxylase protein concentration for the 20 control subjects was $1.16 \pm 0.12(\mathrm{SD}) \mathrm{mg} / \mathrm{l}$, the serum galactosylhydroxylysyl glucosyltransferase activity $0.33 \pm 0.03 \mathrm{U} / 1$ and the serum aminoterminal propeptide of type III procollagen concentration $11.84 \pm 1.45 \mu \mathrm{g} / \mathrm{l}$. The corresponding upper normal limits defined as the mean $+2 \mathrm{SD}$, were thus $1.40 \mathrm{mg} / \mathrm{l}, 0.39 \mathrm{U} / \mathrm{l}$ and $14.74 \mu \mathrm{g} / \mathrm{l}$. Any individual values exceeding the upper normal limits were considered pathological (fig. $1 \mathrm{a}, \mathrm{b}$ and c).

The mean values for serum immunoreactive prolyl hydroxylase protein $(1.62+0.38 \mathrm{mg} / \mathrm{l})$, serum galactosylhydroxylysyl glucosyltransferase activity $(0.56 \pm 0.20 \mathrm{U} / 1)$ and serum aminoterminal propeptide of type III procollagen $(21.23 \pm 14.00 \mu \mathrm{g} / \mathrm{l})$ were all elevated highly significantly $(p<0.001)$ in the cases of the sickle cell disease compared to the normals. Fifteen patients or 75 percent of the cases investigated had serum immunoreactive prolyl hydroxylase protein and serum galactosylhydroxylysyl glucosyltransferase activity values exceeding the upper normal limits (fig. $1 \mathrm{a}$ and $1 \mathrm{c}$ ), while 11 patients or 55 percent had serum aminoterminal propeptide 

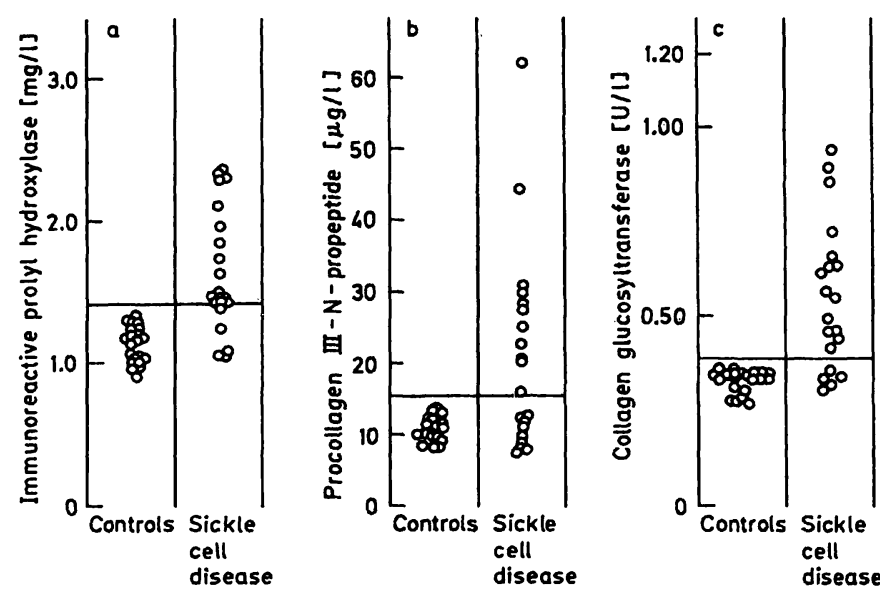

Fig. 1 a. Serum immunoreactive prolyl hydroxylase in controls and patients with sickle cell disease. The horizontal line indicates the mean $+2 \mathrm{SD}$ of the controls.

Fig. 1 b. Serum procollagen III-amino-propeptide in controls and patients with sickle cell disease. The horizontal line indicates the mean $+2 \mathrm{SD}$ of the controls.

Fig. 1 c. Serum collagen glucosyltransferase catalytic concentration in controls and in patients with sickle cell disease. The line drawn horizontally indicates the mean $+2 \mathrm{SD}$ of the controls.

of type III procollagen values exceeding the upper normal limit (fig. $1 \mathrm{~b}$ ). The data of the present investigation confirm the results of earlier morphological studies, which demonstrated collagen fibers and basement membranes in the livers and other organs of patients with sickle cell disease (16-19). All 11 patients who had elevated serum aminoterminal propeptide of type III procollagen concentrations also had increased serum immunoreactive prolyl hydroxylase protein and serum galactosylhydroxylysyl glucosyltransferase activity values.

The mean serum alanine aminotransferase in 15 patients with measured serum collagen enzymes and type III procollagen aminopropeptide was $15.53 \pm$ $13.9 \mathrm{U} / \mathrm{l}$. Grossly elevated values of alanine aminotransferase were observed in 3 of these 15 cases of sickle cell disease. All 3 patients had increased serum immunoreactive prolyl hydroxylase protein, serum galactosylhydroxylysyl glucosyltransferase activity and serum aminoterminal propeptide of type III procollagen values.

Significant correlations were found between various pairs of values from the four tests, but not between the serum aminoterminal propeptide of type III procollagen and alanine aminotransferase test within the group of patients studied (tab. 1).
Tab. 1. Correlation between serum immunoreactive prolyl hydroxylase protein (S-IRPH), serum galactosylhydroxylysyl glucosyltransferase activity (S-GGT), serum aminoterminal propeptide of type III procollagen (S-Pro(III)-N-P) and alanine aminotransferase (ALAT) in patients with sickle cell disease.

\begin{tabular}{lll}
\hline Pair of assays & $\mathrm{r}$ & $\mathrm{p}$ \\
\hline S-IRPH and S-GGT & 0.676 & $<0.001$ \\
S-IRPH and S-Pro(III)-N-P & 0.420 & $<0.05$ \\
S-GGT and S-Pro(III)-N-P & 0.699 & $<0.001$ \\
S-IRPH and ALAT & 0.628 & $<0.001$ \\
S-GGT and ALAT & 0.647 & $<0.001$ \\
ALAT and S-Pro(III)-N-P & 0.387 & $<0.1$ \\
\hline
\end{tabular}

\section{Discussion}

The data reported here clearly demonstrate that serum immunoreactive prolyl hydroxylase protein, serum galactosylhydroxylysyl glucosyltransferase activity and serum aminoterminal propeptide of type III procollagen are elevated in cases of sickle cell disease. A high correlation was found between all three serum markers of collagen biosynthesis, within the group of patients studied, suggesting diffuse fibrogenesis. High correlations have previously been found between the three serum markers in patients with various liver diseases $(6,9,11)$, and are now demonstrated in sickle cell disease. Correlation of the two serum enzymes and serum aminoterminal propeptide of type III procollagen with tests of liver function have been reported earlier $(10,11,13)$, and here there were significant correlations between the two serum enzymes of collagen and serum alanine aminotransferase, but a very week correlation was found between alanine aminotransferase and serum aminoterminal propeptide of type III procollagen. It thus seemed likely that the two serum enzymes and serum aminoterminal propeptide of type III procollagen primarily reflect in sickle cell disease the actual changes in hepatic, bone or spleen collagen formation. Other liver enzyme assays such as aspartate aminotransferase, alkaline phosphatase and $\gamma$-glutamyl transferase may have been very helpful but these were not done due to lack of enough serum samples.

It may be noted that none of these three markers of collagen biosynthesis is entirely specific for liver involvement in sickle cell disease, so diffuse fibrotic changes in other organs, such as the spleen or bone of these patients, may also contribute to the elevated values of these enzymes of collagen synthesis and serum aminoterminal propeptide of type III procollagen. 


\section{Acknowledgement}

This work was supported by a fellowship to the author from the Sigrid Juselius Foundation of Finland to work in the

\section{References}

1. Rojkind, M. \& Kershenobich, D. (1981) Clin. Gastroenterol. 10, 737-254.

2. Bornstein, P. \& Sage, H. (1980) Ann. Rev. Biochem. 49, 957-1003.

3. Pott, G. \& Gerlach, U. (1980) Enzyme 25, 394-406.

4. Prockop, D. J., Kivirikko, K. L., Tuderman, L. \& Guzman, N. A. (1979) N. Engl. J. Med. 301, 13-23, 77-85.

5. Bolarin, D. M. (1983) Res. Comm. Chem. Pathol. Pharmacol. 39, 493-502.

6. Bolarin, D. M., Savolainen, E. R. \& Kivirikko, K. I. (1984) Europ. J. Clin. Invest. 14, 90-95.

7. Kivirikko, K. I. \& Myllyla, R. (1980) The hydroxylation of prolyl and lysysl residues. In: The enzymology of posttranslational modification of proteins (Freedman, R. B. \& Hawkind, H.C., eds.) London, Academic Press, pp. 53-104.

8. Kivirikko, K. I. \& Myllyla, R. (1979) Int. Rev. Connect. Tiss. Res. 8, 23-72.

9. Bolarin, D.M., Savolainen, E.-R. \& Kivirikko, K. I. (1982) Int. J. Cancer 29, 401-405.

10. Kutti-Savolainen, E.-R., Anttinen, H., Miettinen, T. A. \& Kivirikko, K. I. (1979) Eur. J. Clin. Invest. 9, 97-101.
Department of Medical Biochemistry, University of Oulu, Finland.

11. Savolainen, E. R., Miettinen, T. A., Pikkarainen, P., Sala= spuro, M. \& Kivirikko, K. I. (1983) Gut 24, 136-142.

12. Tuderman, L., Risteli, J., Miettinen, T. A. \& Kivirikko, K. I. (1977) Eur. J. Clin. Invest. 7, 537-541.

13. Kutti-Savolainen, E.-R., Risteli, J., Miettinen, T. A. \& Kivirikko, K. I. (1979) Eur. J. Clin. Invest. 9, 89-95.

14. Rohde, H., Vargas, L., Hahn E., Kalbfleisch, H., Bruguera, M. \& Timpl, R. (1979) Eur. J. Clin. Invest. 9, 451-459.

15. Ackermann, W., Pott, G., Voss, B., Müller, K. M. \& Gerlach, U. (1981) Clin. Chim. Acta 112, 363-369.

16. Bogoch, A., Casselman, W. G. B., Margolies, M. P. \& Bockus, H. L. (1955) Am. J. Med. 19, 583-609.

17. Murphy, R. O., Jr. \& Shapiro, S. (1945) Ann. Intern. Med. $23,376-397$.

18. Owen, D. M., Aldridge, J. E. \& Thompson, R. B. (1965) Am. J. Med. Sci. 249, 175-185.

19. Rosenblate, H. J., Eisenstein, R. \& Holmes, A. W. (1970) Arch. Pathol. 90, 235-245.

20. Myllyla, R., Risteli, L. \& Kivirikko, K. I. (1975) Eur. J. Biochem. 52, 401-410.

21. Anttinen, H. (1977) Clin. Chim. Acta 77, 323-330.

Dr. Debayo M. Bolarin, MD, D. Phil. (Oxon) Department of Clinical Pathology College of Medicine University of Lagos

P. M. B. 12003

Lagos

Nigeria 